\title{
Development of Sustainable Textiles from Kenaf-Cotton Blended Yarn
}

\author{
Ramakrishna G*, Srinivasan J, Niveda and Gowtham S \\ Department of Fashion Technology, Kumaraguru College of Technology, India \\ *Corresponding author: Ramakrishna G, Department of Fashion Technology, Kumaraguru College of Technology, India \\ Submission: 酸 November 16, 2017; Published: 眥 February 16, 2018
}

\begin{abstract}
In the recent years, developing new yarn is the fundamental phenomenon for technical textiles. Different yarns are required now days for both technical as well as for aesthetic properties. Kenaf has good antimicrobial, fire resistance and absorbency that can be utilized in various textiles needed for society. The Kenaf cotton blended yarn of 50\%-50\% was produced through rotor spinning and was spun into $10 \mathrm{Ne}$ count. The quality was evaluated for yarn strength, yarn elongation, evenness and hairiness. The quality parameters of kenaf-cotton blended yarn were compared to $100 \%$ cotton yarn. The results reveal that the kenaf-cotton blended yarn were in comparable quality with $100 \%$ cotton and can be made into fabrics of different weave structures and can be utilized for various potential applications like home textiles and medical textiles focusing towards a sustainable environment.

Keywords: Kenaf; Cotton; Yarn; Quality; Sustainability
\end{abstract}

\section{Introduction}

Substantial amount of textiles is now used in homes to make life more comfortable. Textiles are also widely used in many industrial and technical textiles. Fabrics in earlier days were derived from fibers of animals and natural plant sources. In addition, social, psychological, physiological, physical economic parameters play a vital role in the selection of textile products, wearing and purchase decision.

Kenaf is a cellulosic fiber also known as Hibiscus Cannabinus $\mathrm{L}$, which is grown in 12 states in India [1]. It grows in all soils at all climatic conditions with minimal amount of water for its growth [2]. The fibers are around $1 \mathrm{~m}$ to $1.5 \mathrm{~m}$ in length. It has got good absorbency, fire resistance and antimicrobial properties that can be utilized in textiles for various applications [3]. It is not affected by humidity and has excellent sound insulation and thermal insulation properties [4]. Single yarn fabric posses only the properties of one fiber but blended yarn posses the properties of both the fibers and hence they have unique characteristics Salam et al. [5], currently various researches are taking place on yarns and fabrics made from kenaf fiber. Some of them include researches on carding of the bast fibers Tao et al. [6], retting conditions for separating the bast fibers Lee et al. [7], Lee et al. [8], Morrision et al. [9], Parikh et al. [10] Wang et al. [11], physical/chemical properties of kenaf fibers $[8,9,12]$,blending kenaf fibers with cotton Ramaswamy et al. [13] , Ramaswamy et al. [14] and rayon Lee et al. [15]and researches on nonwovens with kenaf fiber Parikh et al. [16]. These researches not only focuses towards sustainable development but also adds value to the crop.
This research mainly focuses towards the development of kenaf cotton blended yarn and evaluation of the quality parameters of the yarn that can be fabricated and used in various fields of textiles.

\section{Material and Methods}

\section{Selection of fibers}
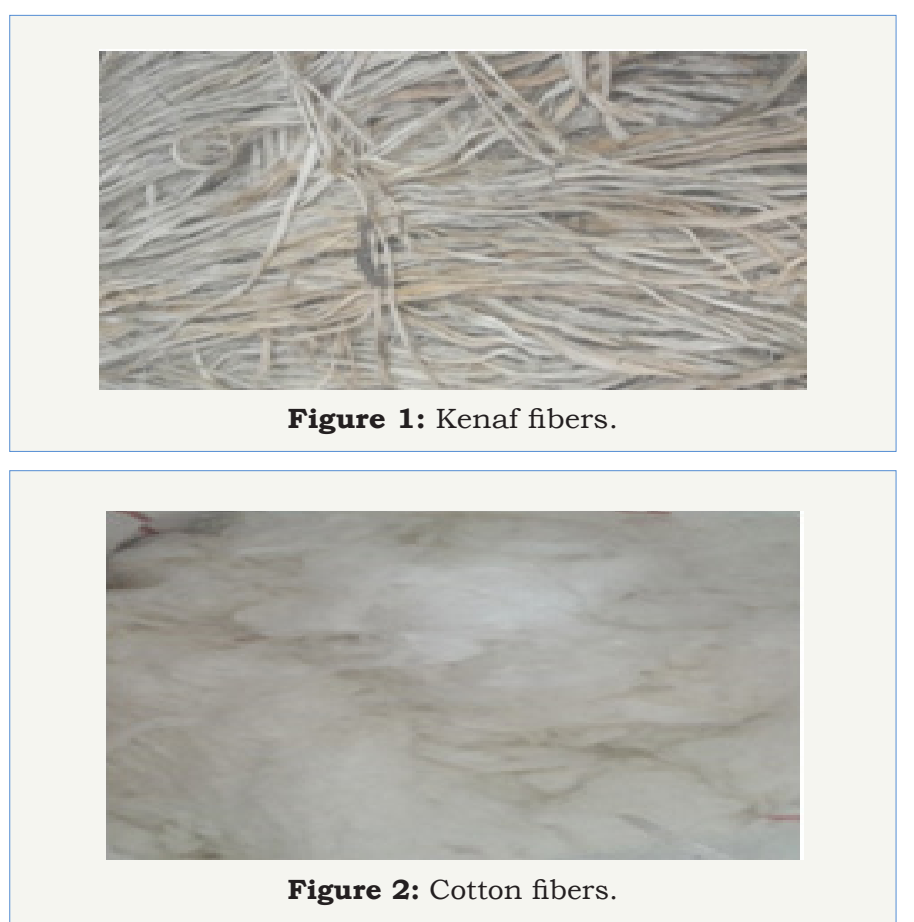

Kenaf fibers and cotton fibers were purchased from Bharatiya natural fibers, Coimbatore (Figure $1 \& 2$ ). 


\section{Properties and cross sectional view of kenaf fiber}

Table 1: Kenaf and cotton fiber properties.

\begin{tabular}{|c|c|c|}
\hline Properties & GOG & Cotton \\
\hline Density $\left(\mathrm{gm} / \mathrm{cm}^{3}\right)$ & 1.45 & $1.5-1.6$ \\
\hline Diameter $(\mu \mathrm{m})$ & $40-90$ & $16-21$ \\
\hline Elongation $(\%)$ & 1.6 & $7-8$ \\
\hline Tensile strength(MPa) & 930 & 400 \\
\hline Modulus(GPa) & 53 & $5.5-12.6$ \\
\hline
\end{tabular}

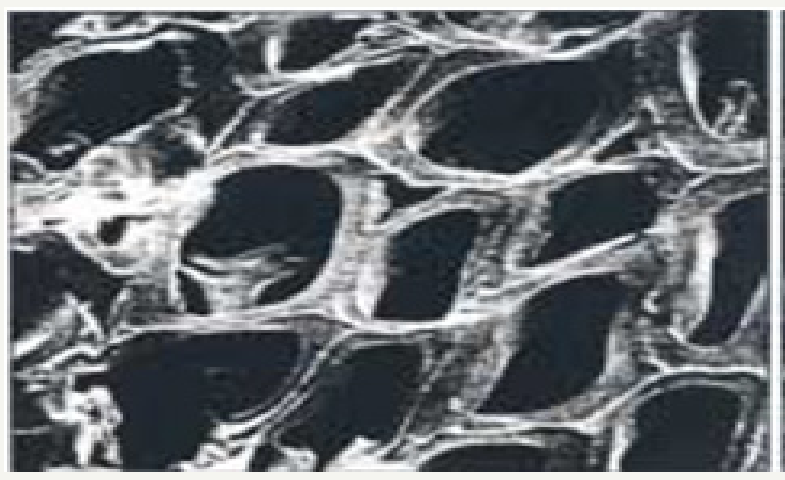

Figure 3: Cross sectional view of kenaf fibers Moreau et al. [19].

Through visual inspection, Kenaf fibers are generally coarser than the cotton fibers Napisah et al. [17] \& bio resin based natural fibre [18]. The properties of both the kenaf and cotton are discussed in Table 1 \& Figure 3 [19].

\section{Softening of kenaf fiber}

The fiber bundles were taken and were soaked in a vessel containing water. The vessel containing the Kenaf fibers were allowed to boil for 3 hours. After 3 hours the fibers were taken out and were allowed to dry.

\section{Blending of kenaf and cotton}

The softened fibers were cut in the length of 1 inch. The cut fibers were blended with cotton of length $30 \mathrm{~mm}$ in the ratio $50 \%$ $50 \%$ blend ratio.

\section{Carding}

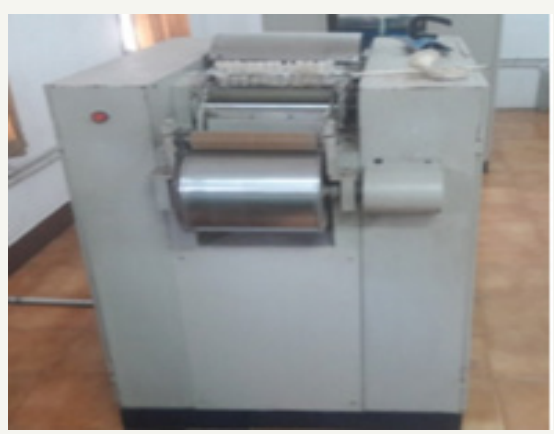

Figure 4: Miniature carding machine.

It is a mechanical process that cleans and mixes fibers to produce webs or sliver suitable for subsequent processing. The fibers are passed through various rollers of different surfaces. It breaks the clumps formed in the fibers and then parallelizes the fiber. The kenaf fiber and the cotton fiber in the 50\%:50\% ratio was blended and was carded in a miniature carding machine and kenaf cotton webs were formed at first stage. The kenaf cotton webs produced were again carded to form the carded sliver (Figure 4).

\section{Open end spinning}

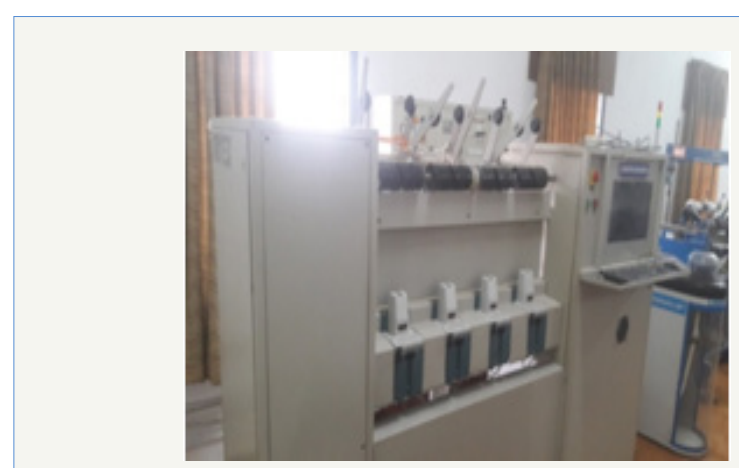

Figure 5: Miniature open end spinning machine.

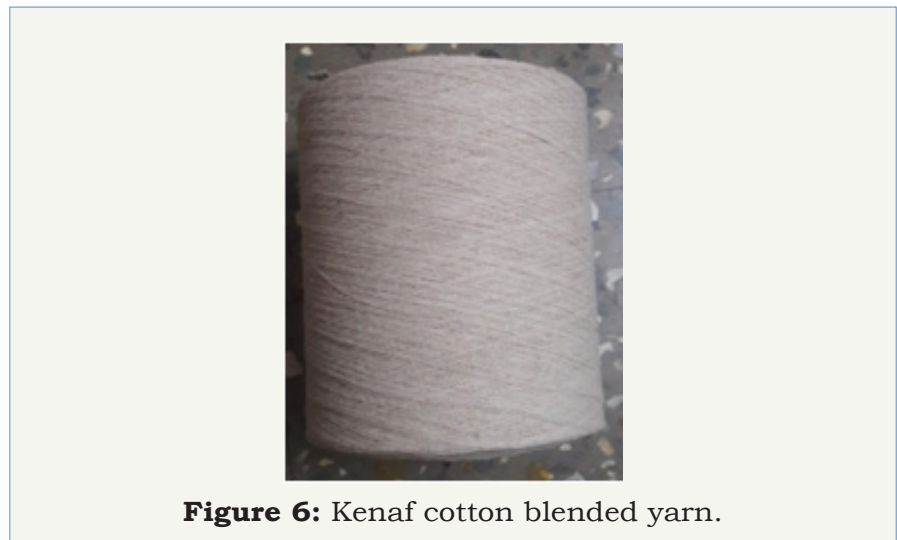

The carded slivers were spun in an open end spinning with rotor speed being 3000Rpm, open roller speed being $1100 \mathrm{Rpm}$ and twist being and twist direction being $\mathrm{z}$ direction. The yarns were produced in 10 s count (Figure $5 \& 6$ ).

\section{Determination of mechanical properties of kenaf cotton blended yarn}

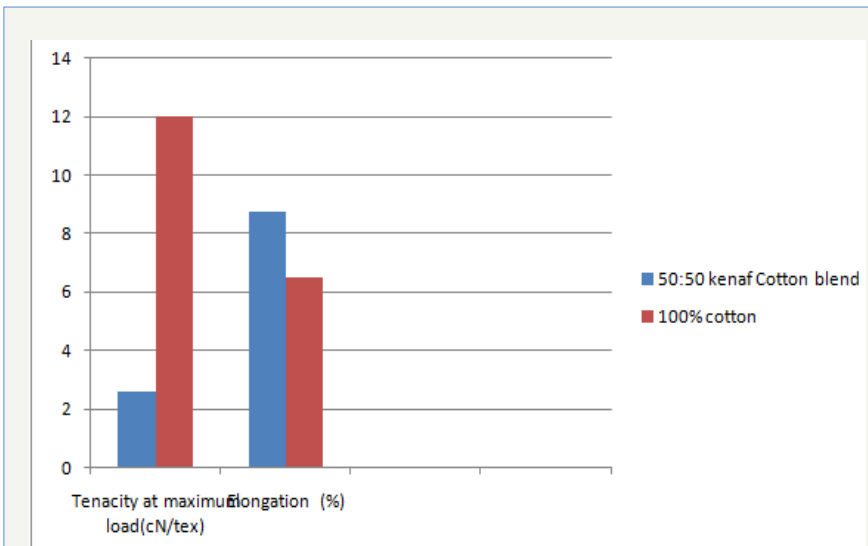

Figure 7: Mechanical properties of kenaf cotton blended yarn. 
Yarn strength was tested in a Universal Single column Instron tensile testing machine Model-3345. The values of Extension at maximum load (mm), Tenacity at maximum load (cN/tex) were determined and were compared to $100 \%$ cotton yarns [20], (Figure 7).

\section{Yarn evenness}

Table 2: Evenness value of kenaf cotton blended yarn.

\begin{tabular}{|c|c|c|}
\hline Particulars & $\begin{array}{c}\mathbf{5 0 : 5 0} \text { Kenaf cotton } \\
\text { yarn }\end{array}$ & $\begin{array}{c}\mathbf{1 0 0 \%} \text { Cotton } \\
\text { yarn }\end{array}$ \\
\hline Uster CV\% & 28.01 & $13-14.5$ \\
\hline Thin places(-50\%)/km & 1186 & $1-15$ \\
\hline Thick places(+50\%)/km & 876 & $30-80$ \\
\hline Neps (+200\%)/km & 1468 & $8-50$ \\
\hline
\end{tabular}

Yarn evenness test was taken as per ASTM D 1425/D 1425M:2014 to find the U\%, Imperfections (For OE) at R.H. 65\%+/2\%, Temp.21 Degree C+/-1 Degree C, Nom. twist 0 T/m, v=400m/ $\min , \mathrm{t}=0.25 \mathrm{~min}$ and were compared to $100 \%$ cotton yarn [20] (Table 2).

\section{Results and Discussion}

Kenaf cotton yarns were produced and were compared to the yarns produced from $100 \%$ cotton yarn [19]. The yarns produced had nominal strength. Due to the nominal strength of the yarn, elongation of the yarn was good. The U\% of the yarn was $23 \%$ which is suitable to be spun into fabrics of various weave structures. Generally, the rotor spun yarns have less hairs than the ring spun yarns Zhang et al. [21].

\section{Conclusion}

Thus kenaf cotton blended yarns were successfully produced. Blended yarns are usually coarser than the single yarns. Softening with enzymes can also be implemented to improve the quality of this kenaf cotton yarn for textile applications. The yarns produced were not superior to $100 \%$ cotton yarns yet these yarns have various other attributes like color, luster, texture, appearance etc... Kenaf has various other natural properties like absorbency, fire resistant, sound insulation, Thermal insulation that will create a great impact on industrial textiles. The fabrics produced from these yarns can be used for bags, mats, home textiles, outer wear etc... Making use of kenaf fibers for various potential applications may also expand the cultivation of kenaf fibers.

\section{Acknowledgement}

The authors are grateful to the management of Kumaraguru College of Technology, Coimbatore, TIFAC-CORE and Natural Fiber Research Centre (NFRC) of Kumaraguru College of Technology, Coimbatore, India.

\section{Conflict of Interest}

The authors declare no conflict of interest.

\section{References}

1. http://assamagribusiness.nic.in/mesta.pdf

2. https://www.daf.qld.gov.au/plants/field-crops-and-pastures/sugar/ complementary-crops/kenaf

3. http://www.fibre2fashion.com/industry-article/6856/ecologyeconomy-and-equity?page $=2$

4. http://www.termoisolanti.com/en/products/green-building/moredetails-on-green-building/kenaf-fibre.php?lang=EN

5. Salam MA, Farouqui FI, Md Mondal IH (2007) A study on sulphonated jute-cotton blended yarn and fabrics and their characteristics. Bangladesh Journal of Scientific and Industrial Research 42 (3): 281-286.

6. Tao W, Calamari TA, Crook L (1998) Carding kenaf for nonwovens. Textile Research Journal 68(6): 402-406.

7. Lee HJ, Ahn CS, Kim JH, Yoo HJ, Han YS, et al. (2004) Effect of enzyme retting on the fiber separation of kenaf bast: influence of chelator Journal of the Korean Society of Clothing and Textiles 28(7): 873-881.

8. Lee HJ, Han YS, Yoo HJ, Kim JH, Song KH, et al. (2003) Effect of chemical retting on the fiber separation of kenaf bast. Journal of the Korean Society Clothing Textiles 27(9/10): 1144-1152.

9. Morrision WH, Akin DE, Ramaswamy G, Baldwin B (1996) Evaluating chemically retted kenaf using chemical, histochemical, and microspectrophotometric analyses. Textile Research Journal 66(10): 651-656.

10. Parikh DV, Calamari TA, Sawhney APS, Blanchard EJ, Screen FJ, et al. (2002) Improved chemical retting of kenaf fibers. Textile Research Journal 72(7): 618-624.

11. Wang J, Ramaswamy GN (2005) Physical and chemical properties of wet processed hemp and kenaf. AATCC Review 5(1): 22-26.

12. Wang J, Ramaswamy GN (2003) One step processing and bleaching of mechanically separated kenaf fibers: effects on physical and chemical properties. Textile Research Journal 73(4): 339-344.

13. Ramaswamy GN, Body CR, Bel-Burger P, Kimmel L (1995) Kenaf/Cotton Blends for Textiles. Family Consumer Sciences Research Journal 24(2): 180-190.

14. Ramaswamy GN, Easter EP (1997) Durability and aesthetic properties of kenaf/cotton blend fabrics. Textile Research Journal 67(11): 803-808.

15. Lee HJ, Ahn CS, Kim GH, Yoo HJ, Han YS, et al. (2004) Characteristics of kenaf/rayon fabrics. Journal of the Korean Socience Clothing Textiles 28(910): 1282-1291.

16. Parikh DV, Calamari TA, Sawhney APS, Blanchard EJ, Screen FJ, et al (2002) Thermoformable automotive composites containing kenaf and other cellulosic fibers. Textile Research Journal 72(8): 668-672.

17. Napisah S, Aidah J, Hakim RN (2014) Tensile and compressive properties of hybrid carbon fiber/kenaf polymer composite. Advances in Environmental Biology 8(3): 1-7.

18. https://www.slideshare.net/PadmanabhanKrishnan2/bio-resin-basednatural-fibre-composites-and-their-applications

19. Moreau JP, Bel-Berger P, Tao W (1995) Mechanical processing of kenaf for nonwovens. Tappi Journal 78(2): 96-105.

20. (2011) Basic structural features of spun yarn. Spinning.

21. Zhang Ting (2003) Improvement of kenaf yarn for apparel applications, Beijing university of chemical technology, China. 
Your subsequent submission with Crimson Publishers will attain the below benefits

- High-level peer review and editorial services

- Freely accessible online immediately upon publication

- Authors retain the copyright to their work

- Licensing it under a Creative Commons license

- Visibility through different online platforms

- Global attainment for your research

- Article availability in different formats (Pdf, E-pub, Full Text)

- Endless customer service

- Reasonable Membership services

- Reprints availability upon request

- One step article tracking system 